\title{
Octreotide inhibits the enterochromaffin-like cell but not peroxisome proliferator-induced hypergastrinemia
}

\section{Bakke, A K Sandvik and H L Waldum}

Department of Physiology and Biomedical Engineering, Norwegian University of Science and

Technology, and Department of Medicine, University Hospital of Trondheim, Trondheim, Norway

(Requests for offprints should be addressed to I Bakke, Department of Physiology and Biomedical

Engineering, Faculty of Medicine, Norwegian University of Science and Technology,

N-7489 Trondheim, Norway; Email: Ingunn.Bakke@medisin.ntnu.no)

\begin{abstract}
The peroxisome proliferator ciprofibrate induces hypergastrinemia and as a consequence, enterochromaffin-like (ECL) cell hyperplasia. The mechanism for the gastrin cell stimulation is unknown. The somatostatin analog octreotide LAR (long-acting release) was used to see if the stimulating effects of ciprofibrate could be attenuated. Female Fischer rats were dosed with ciprofibrate $(50 \mathrm{mg} / \mathrm{kg}$ body weight per day) alone or combined with octreotide LAR (10 mg/30 days) for 60 days. Plasma gastrin and histamine, gastric endocrine cell densities and mRNA abundances were measured. Ciprofibrate increased gastrin mRNA abundance $(P<0 \cdot 05)$, gastrin cell number $(P<0.001)$ and cell area $(P<0.01)$, and induced
\end{abstract}

hypergastrinemia $(P<0 \cdot 001)$. These rats had profound ECL cell hyperplasia, confirmed by an increase in chromogranin $\mathrm{A}(\mathrm{CgA})$ and histidine decarboxylase (HDC) mRNA, density of neuroendocrine and ECL cells and plasma histamine levels (all $P<0 \cdot 001$ ). Octreotide LAR did not affect ciprofibrate stimulation of gastrin cells, but all parameters of ECL cell hyperplasia were reduced $(P<0 \cdot 001)$. Octreotide LAR also significantly inhibited basal ECL cell function and growth. Ciprofibrate stimulates gastrin cell activity by a mechanism unaffected by octreotide, but octreotide does inhibit basal and gastrin-stimulated ECL cell function and growth.

Fournal of Molecular Endocrinology (2000) 25, 109-119

\section{INTRODUCTION}

The peroxisome proliferator group of substances have a tumorigenic effect on the liver, inducing hyperplasia and hepatocellular carcinomas (Issemann \& Green 1990). The exact mechanism for the neoplastic effect is not known, but it is non-genotoxic (O'Brien et al. 1996). Some of these substances, like ciprofibrate and other fibrates (phenoxyisobutyrate derivatives), also induce hypergastrinemia under sustained exposure (Eason et al. 1988c, Spencer et al. 1989). Gastrin stimulates function of the enterochromaffin-like (ECL) cell and long-term hypergastrinemia causes ECL cell hyperplasia and carcinoids (Ryberg et al. 1989).

The mechanism for the stimulating effect of fibrates on the gastrin-producing $G$ cell is also unknown. Previously, it was claimed that the hypergastrinemia was secondary to reduced gastric acidity (Eason et al. 1988a,b), similar to treatment with proton pump inhibitors and histamine $\mathrm{H}_{2}$ blockers (Ryberg et al. 1989). However, in recent studies, we have shown that ciprofibrate induces hypergastrinemia without reducing gastric acidity, and that high doses even decrease gastric $\mathrm{pH}$, probably because of the increased stimulatory effect of circulating gastrin (Martinsen et al. 1996). We have also shown that the hypergastrinemic effect of ciprofibrate begins later (14 days) than the effect of gastric acid inhibitors (Ryberg et al. 1989) and that co-administration with omeprazole potentiates the hypergastrinemic effect (Hammer et al. 1998). Thus, ciprofibrate causes hypergastrinemia through a mechanism independent of gastric $\mathrm{pH}$. Ciprofibrate not only increases gastrin mRNA abundance and raises serum gastrin concentration, but also tends to increase expression of somatostatin in the antrum (Hammer et al. 1998, Waldum et al. 1998). This is different from the reciprocal relationship that normally exists between gastrin and somatostatin in the antrum (Lundell et al. 1988, Wu et al. 1991). Similar dual increase of these antral peptides 
is also seen after stimulation with gastrin-releasing polypeptide and administration of glucocorticoids (Holst et al. 1987, Xynos et al. 1987, Sandvik et al. 1989, Okazaki et al. 1993).

Somatostatin is widely distributed in the body, suppressing biological events like hormone release and cell proliferation (Lamberts et al. 1991). In the stomach, D cells are located in proximity to their target cells, and exert a restraint on the secretion of histamine and gastrin (Saffouri et al. 1980, Sandvik \& Waldum 1988, Karnik et al. 1989). Receptors for somatostatin are found on ECL and G cells (Borin et al. 1996, Zaki et al. 1996). Long-acting somatostatin analogs have been developed for therapeutic use and are especially useful in patients with secretory neuroendocrine tumors (Lamberts et al. 1991). Octreotide is effective in controlling hypergastrinemia and in inhibiting both fundic endocrine preneoplastic growth and tumor growth in the stomach (Modlin et al. 1992, Bordi et al. 1993, D’Adda et al. 1996).

The aim of this study was to further assess the so far unknown and maybe novel mechanism for the effect of ciprofibrate on the endocrine cells in the rat stomach, by looking at both changes in morphology of the antral and oxyntic mucosa and the mRNA expression of secretory products. Furthermore, we wanted to see if the somatostatin analog octreotide LAR (long-acting release) could attenuate these effects of ciprofibrate.

\section{MATERIALS AND METHODS}

\section{Materials}

The drugs used were ciprofibrate (2-[4(6-2,2 dichlorocyclopropyl)phenoloxyl]-2-methyl propanoic acid) (Modalim; Sanofi-Synthelabo, Alnwick, Northumberland, UK) and octreotide LAR, a generous gift from Novartis Pharma AG (Basel, Switzerland). Fischer rats were purchased from Møllegaard's Breeding Center (Skensved, Denmark). Immunohistochemistry was done with the avidin-biotin-complex (ABC) technique, using a Vectastain peroxidase-rabbit-ABC-kit (PK-4001) and a peroxidase substrate-kit (AEC SK4200) from Vector Laboratories, Inc. (Burlingame, CA, USA). Antisera used were: rabbit polyclonal anti-histidine decarboxylase (HDC) (cat. no. B260-1; Eurodiagnostics, Malmö, Sweden), rabbit polyclonal anti-chromogranin A (CgA) (cat. no. 20086; INCSTAR, Stillwater, MN, USA), rabbit polyclonal anti-human somatostatin (cat. no. A566) and rabbit polyclonal anti-human gastrin (cat. no. A568) both from DAKO A/S (Glostrup, Denmark) and mouse monoclonal anti- $\beta-\mathrm{H}^{+} / \mathrm{K}^{+} \mathrm{ATPase}$ (cat. no
MA3-923; Affinity BioReagents, Inc., Golden, CO, USA). Histamine RIA kits were purchased from Immunotech (Marseilles, France), ${ }^{32} \mathrm{P}$-labeled nucleotides from Amersham International (Amersham, Bucks, UK), nylon membranes from Boehringer Mannheim (Mannheim, Germany) and NICK columns from Pharmacia Biotech AB (Uppsala, Sweden).

\section{Study design}

The study was approved by the animal welfare committee of the University Hospital of Trondheim. Female Fischer rats $(200-250 \mathrm{~g})$ were assigned to four groups (I-IV) of 12, 14, 12 and 12 rats respectively, and housed in wire-bottom cages at $20{ }^{\circ} \mathrm{C}$ with a relative humidity of $40-45 \%$, a $12 \mathrm{~h}$ light:12 h darkness cycle and free access to commercial rat chow and water. All groups were given $1 \mathrm{ml}$ tap water with or without ciprofibrate $(50 \mathrm{mg} / \mathrm{kg}$ body weight) once daily by gastric intubation. Octreotide LAR or placebo drug $(10 \mathrm{mg})$ was dissolved in $1 \mathrm{ml}$ of the supplied vehicle, and $0.5 \mathrm{ml}$ was injected i.m. in both thighs on day 1 and day 28 of the study period. Group I (control) was given tap water and placebo drug, group II ciprofibrate and placebo drug, group III tap water and octreotide LAR and group IV both ciprofibrate and octreotide LAR. The purpose of this study was to examine the mechanisms of both ciprofibrate and octreotide action on endocrine cells in antral and oxyntic mucosa. Therefore, the doses used were not clinically matched, but instead set very high to ensure maximal effects of the drugs. The depot formulation of octreotide, octreotide LAR, was used because of its convenience in long-term studies, reducing the number of injections and giving a more stable plasma level of the somatostatin analog during the study period. Initially the rats were given $80 \mathrm{mg} / \mathrm{kg}$ ciprofibrate, but because of weight loss in some of the rats after 1 week, the dose was reduced to $50 \mathrm{mg} / \mathrm{kg}$. One rat in group II died after 2 weeks. After injection of octreotide LAR/placebo on day 28 , further weight loss in some rats made it necessary to stop the administration of drug to these rats for 6-12 days.

The rats were weighed at the start and weekly throughout the study. Blood was taken from the femoral vein of anesthetized $(0.3 \mathrm{ml} / 100 \mathrm{~g}$ body weight of $2.5 \mathrm{mg} / \mathrm{ml}$ fluanison, $0.05 \mathrm{mg} / \mathrm{ml}$ fentanyl and $1.25 \mathrm{mg} / \mathrm{ml}$ midazolam) rats on day 1 , day 21 and day 60. Plasma was frozen for later determination of histamine and gastrin by RIA (Kleveland et al. 1985, Waldum et al. 1989). At the end of the study, the rats were anesthetized and killed by decapitation. The stomachs were immediately 
removed, opened at the major curvature and rinsed in saline. Biopsies were taken from the oxyntic and antral mucosa and fixed in $4 \%$ buffered formaldehyde or homogenized for RNA extraction. The homogenates were immediately frozen at $-80{ }^{\circ} \mathrm{C}$.

\section{Immunohistochemical procedures}

Fixed tissue specimens were dehydrated, embedded in paraffin and cut perpendicular to the mucosal surface in $5 \mu \mathrm{m}$ thick sections. Before staining, the sections were dewaxed, rehydrated and treated with $3 \% \mathrm{H}_{2} \mathrm{O}_{2}$ for $10 \mathrm{~min}$. Corpus sections were incubated overnight at $4{ }^{\circ} \mathrm{C}$ with primary antibody to $\mathrm{CgA}$ (1:500 dilution), HDC (1:3000 dilution) and $\mathrm{H}^{+} / \mathrm{K}^{+}$ATPase $(1: 3000$ dilution). The antral sections were incubated overnight at $4{ }^{\circ} \mathrm{C}$ with primary antibody to $\mathrm{CgA}$ (1:500 dilution), gastrin (1:700 dilution) and somatostatin (1:800 dilution). All sections were counterstained with hematoxylin.

Both the number and area of nucleated immunoreactive cells were determined. With a $250 \mu \mathrm{m}$ wide ocular grid (objective $\times 40$; magnification $\times 400$ ), three to five randomly selected areas of the same width as the grid and extending from the gland base to the mucosal surface were counted on coded slides by two different examiners. Area measurements were done using a computer program for image analysis (ACAS 6.0 Cytometry System; AHRENS Datensysteme, Bargteheide, Germany). Areas of approximately $250 \mathrm{~mm}^{2}$ in corpus sections and $130 \mathrm{~mm}^{2}$ in antral sections extending from the base of the glands to the mucosa surface were measured.

\section{mRNA analysis}

Tissue biopsies were homogenized using a rotating-knife homogenizer (Ultra-Turrax, Janke \& Kunkel, IKA-Labortechnik, Staufen, Germany) in a denaturing buffer $(1 \mathrm{ml} / 100 \mathrm{mg}$ tissue) containing $4 \mathrm{M}$ guanidinium isothiocyanate, $25 \mathrm{mM}$ sodium acetate $(\mathrm{pH} 6 \cdot 0)$ and $0 \cdot 84 \%(\mathrm{v} / \mathrm{v}) \beta$-mercaptoethanol. Total RNA was isolated by ultracentrifugation of the homogenates through a cushion of $5 \cdot 7 \mathrm{M}$ cesium chloride and precipitated with ethanol.

HDC, CgA, somatostatin, gastrin and glyceraldehyde 3-phosphate dehydrogenase (GAPDH) probes were made as outlined previously (Angelsen et al. 1997, Sandvik et al. 1997, Hammer et al. 1998). 18S RNA was amplified from total RNA by PCR, using primers corresponding to the 12361253 and 1792-1809 stretches of the rat 18S RNA sequence (Chan et al. 1984) after reverse transcription with the 1792-1809 primer. The product was cloned into the pCRII vector (Invitrogen, San Diego, CA, USA) and verified by sequencing.

www.endocrinology.org
Plasmids were linearized, and antisense RNA probes labeled with ${ }^{32} \mathrm{P}$ by transcription according to standard protocols and purified on NICK columns.

Total RNA $(20 \mu \mathrm{g} /$ well $)$ was electrophoresed in $1 \%$ agarose-formaldehyde gels, electroblotted onto nylon membranes and crosslinked by UV irradiation. Membranes were prehybridized for $4 \mathrm{~h}$ at $65^{\circ} \mathrm{C}$ in $5 \times$ saline-sodium phosphate EDTA (SSPE) buffer $(1 \times \mathrm{SSPE}$ is $0.18 \mathrm{M} \mathrm{NaCl}, 10 \mathrm{mM}$ $\mathrm{NaH}_{2} \mathrm{PO}_{4}$ and $1 \mathrm{mM}$ EDTA, pH 7.4), with 50\% deionized formamide, $5 \times$ Denhardt's solution $(0 \cdot 1 \%$ BSA, polyvinylpyrrolidone, and Ficoll 400) and $0.5 \%$ SDS. Hybridization was done in the same solution with RNA probe $\left(2 \times 10^{6}\right.$ c.p.m. $\left./ \mathrm{ml}\right)$ for $18 \mathrm{~h}$, and thereafter the membranes were washed twice with $2 \times \mathrm{SSPE}$ containing $0 \cdot 1 \%$ SDS for 20 min at room temperature and once in $0.1 \times \mathrm{SSPE}$ with $0 \cdot 1 \%$ SDS at $65{ }^{\circ} \mathrm{C}$. Membranes were exposed to a storage phosphor screen for $24 \mathrm{~h}$, scanned on a PhosphorImager (Molecular Dynamics, Sevenoaks, Kent, UK) and quantified using ImageQuant software (Molecular Dynamics). Stripping between hybridizations was done with boiling $0 \cdot 1 \%$ SDS.

\section{Data analysis and presentation}

Changes in morphology and mRNA expression were examined in five rats from each group. The mRNA values are expressed as percent of controls (group I). Estimations of mRNA sizes were made with reference to the positions of $18 \mathrm{~S}$ and $28 \mathrm{~S}$ ribosomal RNAs. The mRNA abundances were normalized to $18 \mathrm{~S}$ values, and GAPDH abundance was used as a control. The numerical densities of the cells are expressed as the mean number \pm s.E.M. of positive cells/mucosa area in each group. The immunoreactive areas of the different cell types are expressed as the mean positive area \pm S.E.M. in percent of the total area measured. Concentrations of gastrin and histamine in plasma are given as the mean value \pm S.E.M. of measurements done at the start, after 21 days and at the end (60 days). Statistical evaluations between three or more groups were done with a one-way ANOVA and Bonferroni's post-hoc test. Comparisons between two groups were done with an unpaired $t$-test, and for all evaluations $P>0.05$ was considered non-significant.

\section{RESULTS}

\section{Plasma gastrin and histamine concentrations}

Changes in plasma gastrin during the study period (days 0, 21 and 60) are summarized in Fig. 1A. In 

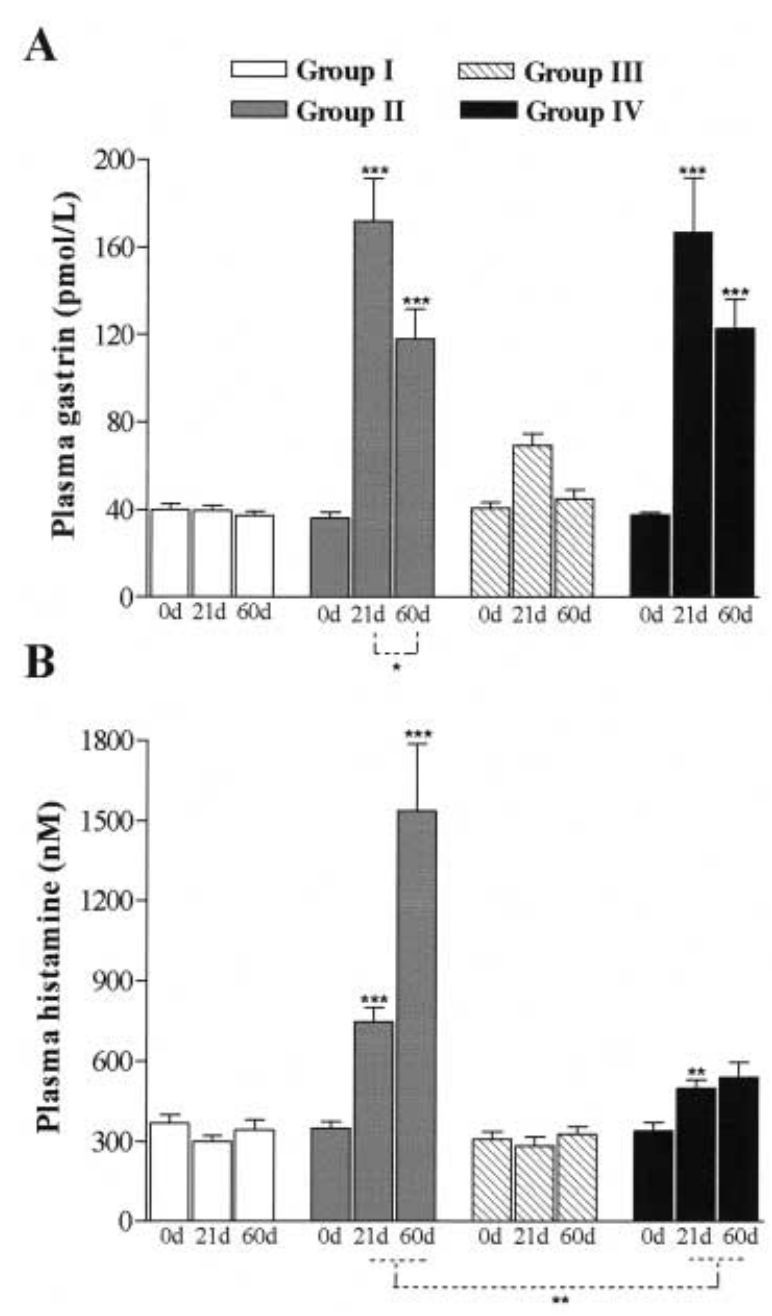

FIGURE 1. Mean plasma gastrin (A) and plasma histamine $(\mathrm{B})$ concentrations at the start $(0 \mathrm{~d})$, after 21 days $(21 \mathrm{~d})$ and at the end $(60 \mathrm{~d})$ in control rats (group $\mathrm{I}$ ) or rats dosed with either ciprofibrate (group II), octreotide LAR (group III) or a combination of both (group IV) for 60 days. All values are mean \pm s.E.M. ** $P<0 \cdot 01$, *** $P<0 \cdot 001$ vs control or as indicated.

the control group and in group III, receiving only octreotide LAR, plasma gastrin concentration did not change significantly and pooled values from both measurements during the study were $38 \pm 1 \mathrm{pmol} / 1 \quad(n=24)$ and $57 \pm 4 \mathrm{pmol} / 1 \quad(n=24)$ respectively. In group II, dosed with ciprofibrate, the gastrin level was raised to $171 \pm 20 \mathrm{pmol} / \mathrm{l}$ at 21 days ( $n=13, P<0.001$ vs control 21 days) and to $118 \pm 14 \mathrm{pmol} / 1$ at 60 days $(n=13, P<0.001$ vs control 60 days and $P<0 \cdot 05$ vs group II 21 days). In group IV, receiving both ciprofibrate and octreotide LAR, plasma gastrin was similar to that in group II, reaching $166 \pm 25 \mathrm{pmol} / \mathrm{l}$ at 21 days and $123 \pm$
$13 \mathrm{pmol} / 1$ at 60 days (both $n=12, \quad P<0.001$ vs control 21 days and 60 days).

Changes in plasma histamine during the study period (days 0, 21 and 60) are summarized in Fig. 1B. In the control group and in group III, receiving only octreotide LAR, plasma histamine concentration did not change significantly and pooled values from all measurements during the study were $320 \pm 23 \mathrm{nM}(n=24)$ and $305 \pm 22 \mathrm{nM}$ $(n=24)$ respectively. In group II, receiving ciprofibrate, the histamine concentration was increased to $746 \pm 54 \mathrm{nM}$ at 21 days $(n=13, P<0 \cdot 001$ vs control 21 days) and further to $1535 \pm 251 \mathrm{nM}(n=13$, $P<0.001$ vs control 60 days) at 60 days. In group IV, receiving both drugs, plasma histamine at both 21 and 60 days was significantly decreased to $499 \pm 30 \mathrm{nM} \quad(P<0 \cdot 05$ vs control 21 days $)$ and $540 \pm 55 \mathrm{nM}$ respectively (both $n=12, P<0.001$ vs group II).

\section{Effects on gene expression in antral mucosa}

The effects on gene expression in antral mucosa are summarized in Figs 2 and 3. Ciprofibrate increased gastrin mRNA abundance in group II $(269 \pm 54 \%$ of basal, $P<0.05$ vs control), receiving only ciprofibrate, and in group IV $(314 \pm 27 \%$ of basal, $P<0 \cdot 01$ vs control), receiving both octreotide LAR and ciprofibrate. Gastrin mRNA was also increased in group III, receiving only octreotide LAR, $(179 \pm 17 \%$ of basal, $P<0 \cdot 01)$. The somatostatin mRNA level $(109 \pm 13 \%$ of basal) in group II was similar to that in the control group, in spite of the increase in gastrin mRNA. This effect was reversed in the group (IV) receiving both octreotide LAR and ciprofibrate, resulting in a reduced somatostatin mRNA abundance $(55 \pm 5 \%$ of basal) compared with the control group (I) $(P<0 \cdot 05)$ and with group II $(P<0 \cdot 01)$. In group III, given only octreotide LAR, both somatostatin ( $40 \pm 4 \%$ of basal) and $\mathrm{CgA}$ ( $49 \pm 6 \%$ of basal) mRNA levels were significantly attenuated, compared with controls (group I) $(P<0 \cdot 01)$. The abundances of GAPDH mRNA were unchanged in all groups compared with control.

\section{Effects on gene expression in oxyntic mucosa}

The effects on gene expression in the oxyntic mucosa are summarized in Figs 3 and 4. Ciprofibrate (group II) increased $\mathrm{CgA}(553 \pm 66 \%$ of basal) and HDC $(527 \pm 76 \%$ of basal) mRNA abundance significantly $(P<0 \cdot 001)$ compared with the control group (I). This increase was attenuated $(P<0 \cdot 001$ vs group II $)$ in group IV receiving octreotide LAR and ciprofibrate, giving $\mathrm{CgA}$ 


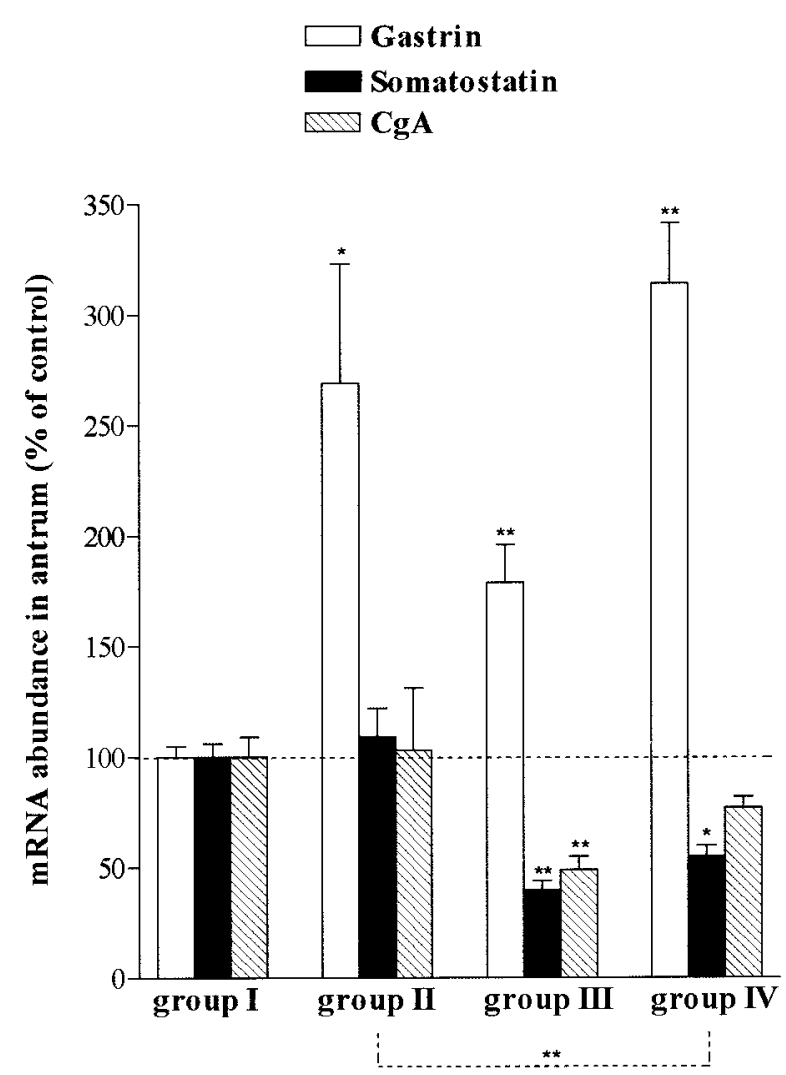

FIGURE 2. Abundance of gastrin mRNA, somatostatin mRNA and CgA mRNA in antral mucosa of control rats (group I) or rats dosed with either ciprofibrate (group II), octreotide LAR (group III) or a combination of both (group IV) for 60 days. All values are mean \pm S.E.M., expressed as percent of the values in group I. ${ }^{*} P<0 \cdot 05$, ** $P<0 \cdot 01$ vs control or as indicated.

$(150 \pm 24 \%$ of basal $)$ and HDC $(168 \pm 27 \%$ of basal $)$ mRNA levels not significantly different from those of the control group. The somatostatin mRNA abundance in both group II ( $45 \pm 3 \%$ of basal) and group IV ( $37 \pm 3 \%$ of basal) was reduced compared with the control group (I) $(P<0,001)$. In group III, receiving only octreotide $\mathrm{LAR}$, the levels of $\mathrm{CgA}$ $(32 \pm 6 \%$ of basal), HDC $(28 \pm 3 \%$ of basal $)$ and somatostatin $(63 \pm 5 \%$ of basal $)$ mRNA were reduced compared with group I $(P<0 \cdot 01)$. The abundances of GAPDH mRNA were unchanged in all groups compared with control.

\section{Changes in histomorphometry of antral and corpus mucosa}

Changes in histomorphometry of antral mucosa are shown in Fig. 5. The number of immunoreactive $\mathrm{G}$ cells in the antrum was increased in all three drug

www.endocrinology.org

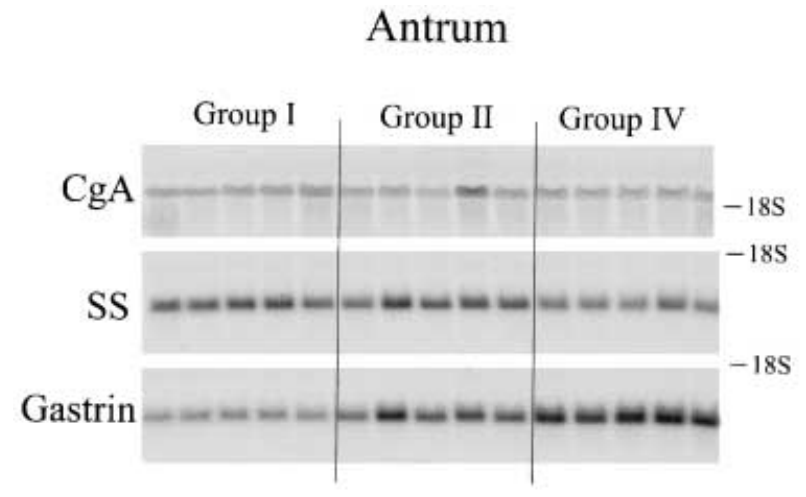

\section{Corpus}

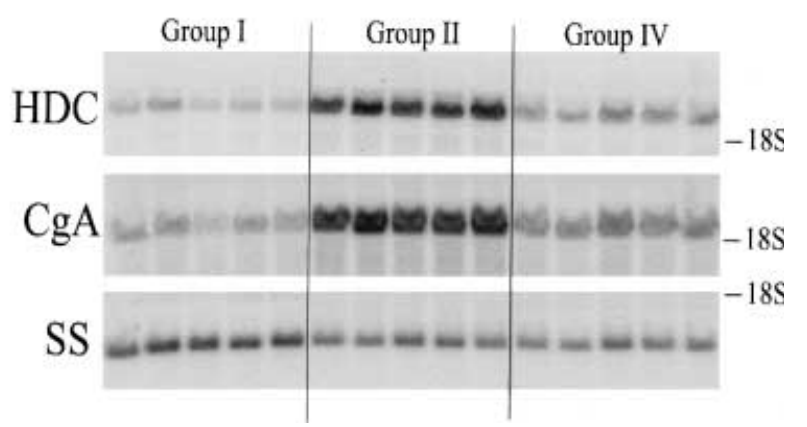

FIGURE 3. Representative Northern blot hybridization patterns with $\mathrm{cRNA}$ probes against $\mathrm{CgA}(\sim 2 \cdot 1 \mathrm{~kb})$, somatostatin $(\mathrm{SS}, \sim 0.85 \mathrm{~kb})$ and gastrin $(\sim 0.65 \mathrm{~kb})$ in antrum, and against $\mathrm{CgA}, \mathrm{SS}$ and $\operatorname{HDC}(\sim 2.5 \mathrm{~kb}$ (major) and $\sim 3.5 \mathrm{~kb}$ (minor)) in corpus of control rats (group I), rats dosed with the ciprofibrate alone (group II) or a combination of ciprofibrate and octreotide LAR (group IV) for 60 days.

groups, reaching $74 \%$ in group II, $61 \%$ in group III and $100 \%$ in group IV (all $P<0 \cdot 001$ ). There were no significant differences between the four groups in the number of $\mathrm{D}$ cells or $\mathrm{CgA}$-immunoreactive cells in antrum. Areas of immunoreactive $\mathrm{G}$ cells were increased $240 \%(P<0 \cdot 01)$ in group II and $208 \%$ $(P<0 \cdot 05)$ in group IV compared with the control group. The area of $\mathrm{D}$ cells or $\mathrm{CgA}$-immunoreactive cells in the antrum did not differ significantly between the four groups. Figure 6 shows examples of gastrin-immunoreactive cells in group II and IV compared with control (group I).

Changes in histomorphometry of oxyntic mucosa are shown in Fig. 7. The number of $\mathrm{CgA}$ immunoreactive and ECL cells in the corpus increased 130 and $327 \%$ respectively in group II, receiving ciprofibrate $(P<0 \cdot 001$ vs. control). In group IV, receiving both drugs, the cell numbers were only 63 and $106 \%$ above the densities in the 


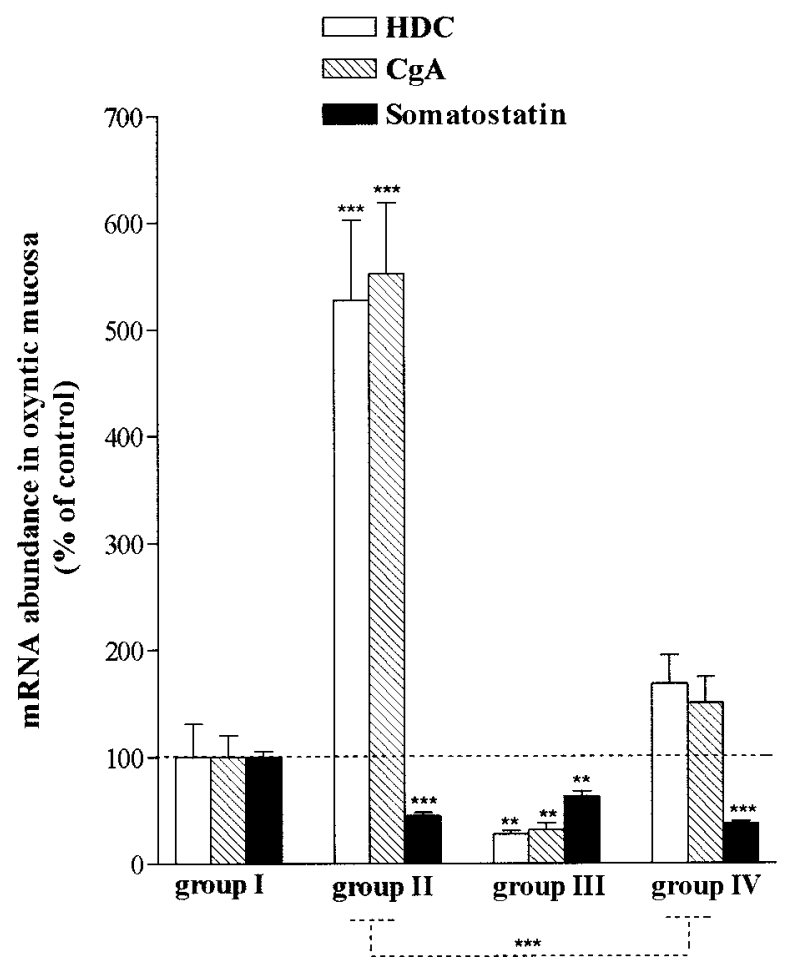

FIGURE 4. Abundance of HDC mRNA, CgA mRNA and somatostatin mRNA in oxyntic mucosa of control rats (group I) or rats dosed with either ciprofibrate (group II), octreotide LAR (group III) or a combination of both (group IV) for 60 days. All values are mean \pm s.E.M., expressed as percent of the values in group I. $* * P<0 \cdot 01, * * * P<0 \cdot 001$ vs control or as indicated.

control group $(P<0 \cdot 001)$ and thus, 29 and $52 \%$ reduced compared with group II $(P<0 \cdot 001)$. In group III, dosed with octreotide LAR alone, the CgA-immunoreactive and ECL cell numbers were reduced 38\% $(P<0.05)$ and $77 \%(P<0 \cdot 001)$ compared with controls. Areas of $\mathrm{CgA}$-immunoreactive and ECL cells in group II increased 190 and 714\% respectively $(P<0 \cdot 001$ vs control). In group IV, receiving both drugs, the areas were reduced $49 \%$ $(P<0.01)$ and $60 \%(P<0.05)$ compared with group II, and were not significantly higher than in the control group. Dosing with octreotide LAR alone also reduced the areas of $\mathrm{CgA}$-immunoreactive and ECL cells, although not significantly. Figure 8 shows examples of HDC-immunoreactive cells in group II and IV compared with control (group I).

The area of parietal cells in the corpus, assessed by computerized image analysis, did not differ between the groups (data not shown).
A
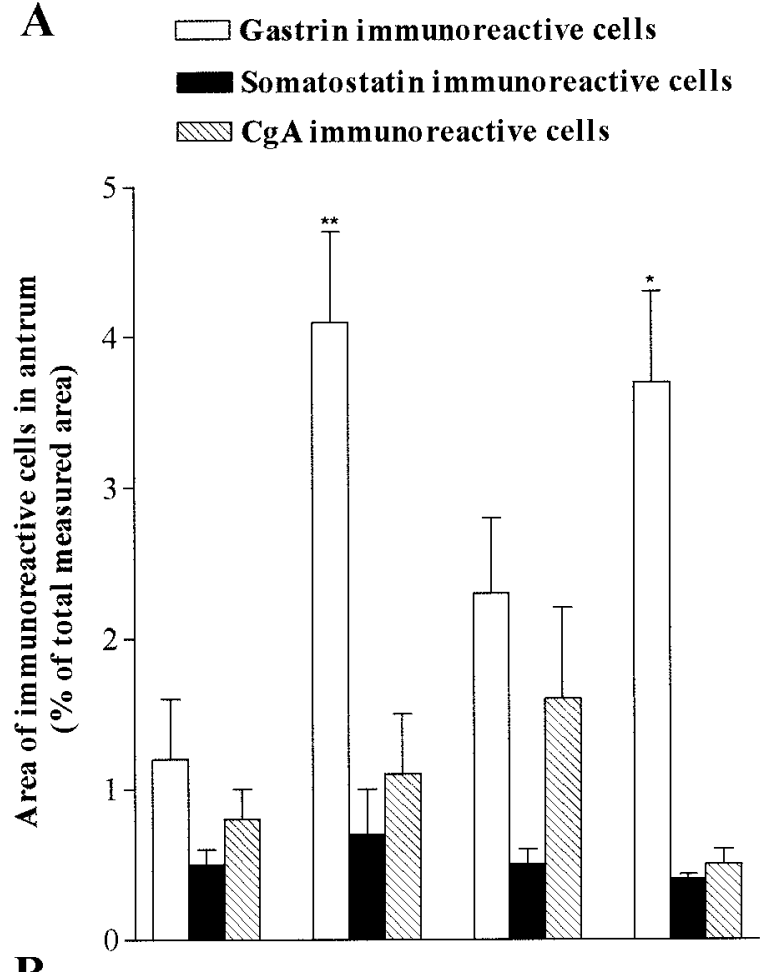

B

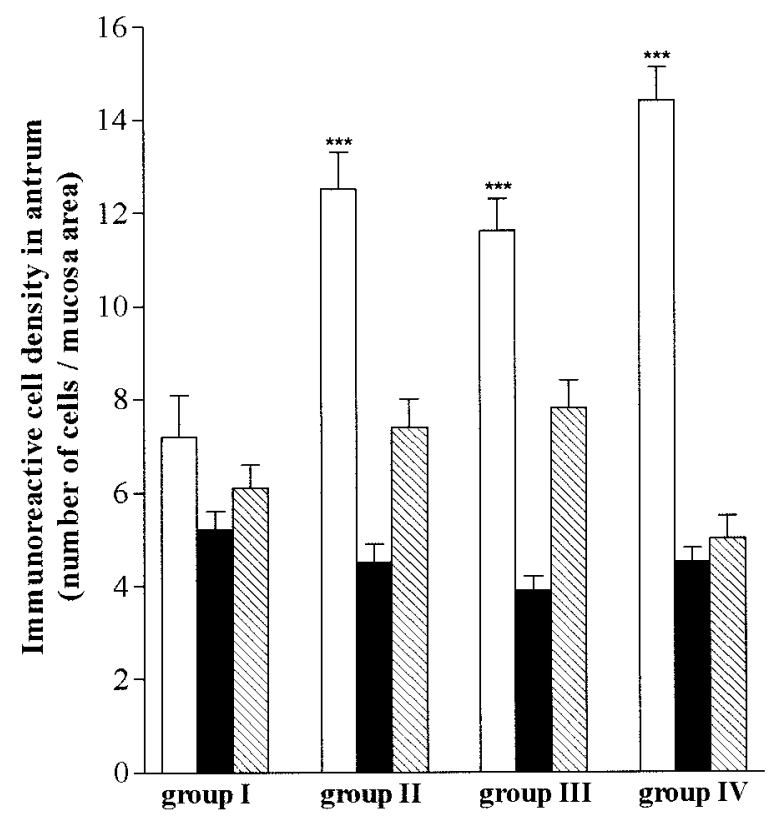

FIGURE 5. Area (A) and density (B) of gastrin-, somatostatin- and $\mathrm{CgA}$-immunoreactive cells in antrum of control rats (group I) or rats dosed with either ciprofibrate (group II), octreotide LAR (group III) or a combination of both (group IV) for 60 days. All values are mean \pm s.E.M. ${ }^{*} P<0 \cdot 05$, $* * P<0 \cdot 01$, ${ }^{*} * * P<0 \cdot 001$ vs control. 
A
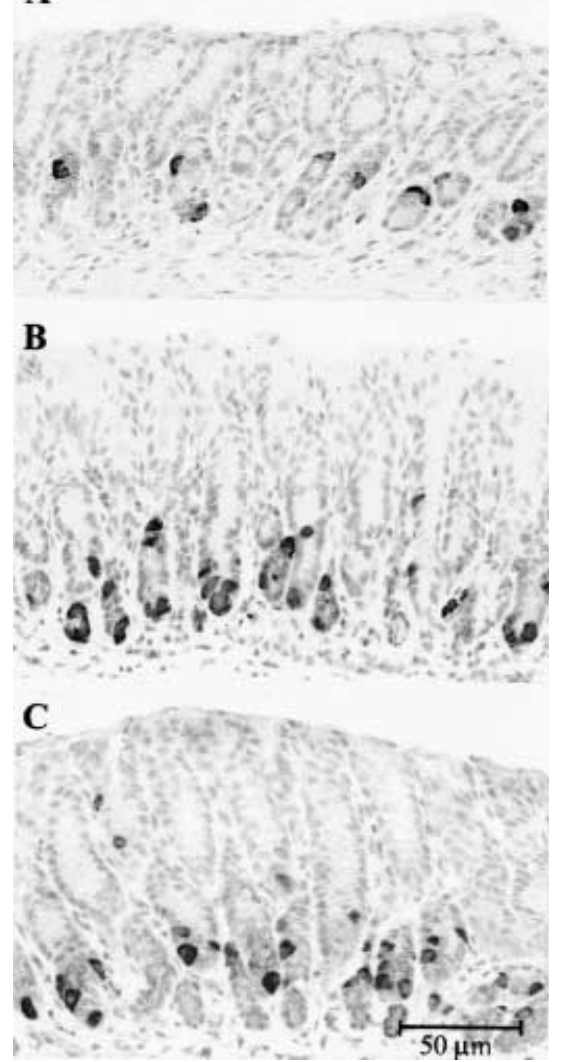

FIGURE 6. Gastrin-immunoreactive cells in antrum of control rats (group I) (A), rats dosed with ciprofibrate (group II) (B), or a combination of ciprofibrate and octreotide LAR (group IV) (C) for 60 days.

\section{DISCUSSION}

This study shows that ciprofibrate increases gastrin mRNA abundance, induces hypergastrinemia and increases both the number and area of $G$ cells, suggesting a modest trophic effect on the $G$ cells. This is consistent with previous studies, showing that ciprofibrate stimulates $G$ cell function and slightly increases $G$ cell density without reducing gastric acidity (Martinsen et al. 1996, Hammer et al . 1998, Waldum et al. 1998). Mild G cell hyperplasia caused by sustained achlorhydria has also been reported by others (Lundell et al. 1988, Kimura 1993), but further proliferation into $G$ cell carcinoids is rare. Normally somatostatin from the $D$ cells in antrum inhibits $G$ cell function (Saffouri et al. 1980, Karnik et al. 1989, Zaki et al. 1996), and the somatostatin analog octreotide has high affinity for somatostatin receptors of subtype 2 (SSTR-2) located on G cells (Zaki et al. 1996). Still, administration of octreotide in combination with
A

HDC immunore active cells

CgA immunoreactive cells
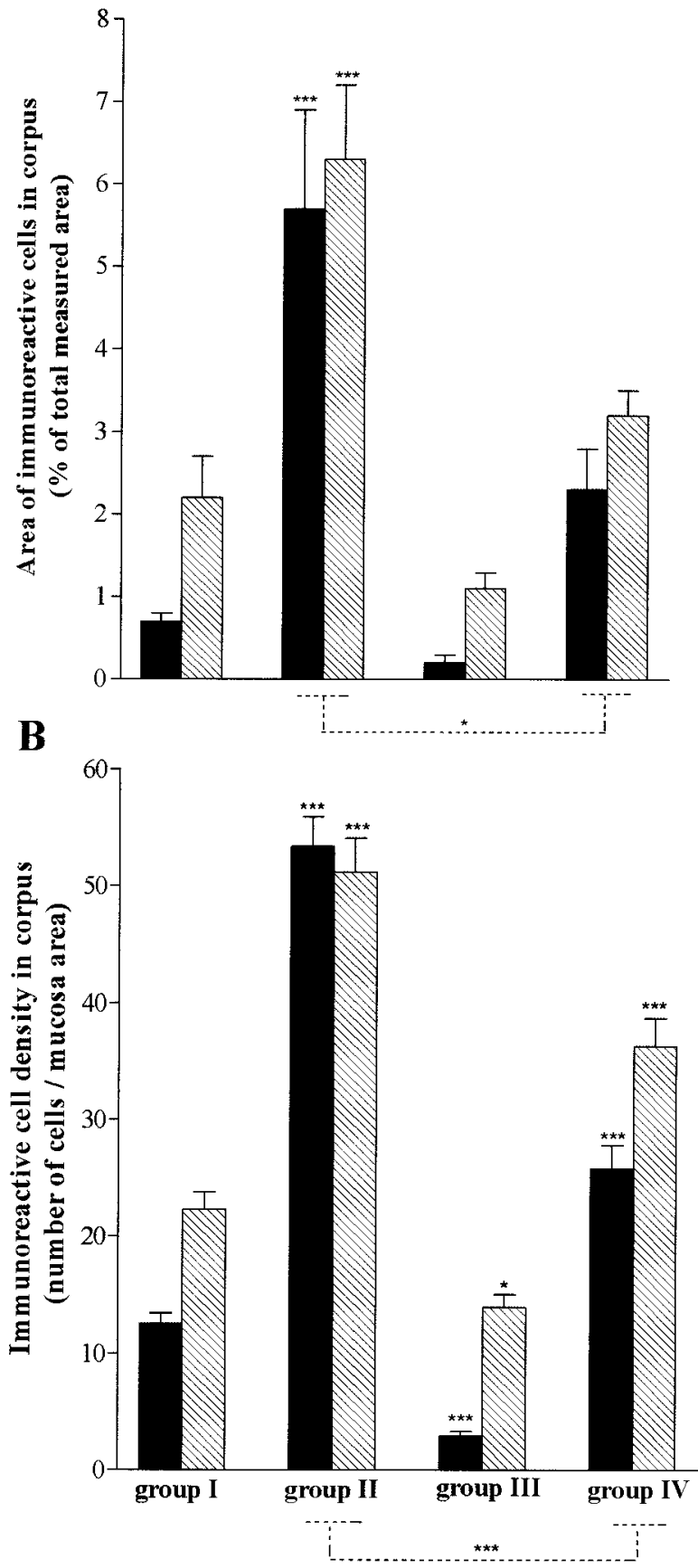

FIGURE 7. Area (A) and density (B) of HDC- and CgA-immunoreactive cells in oxyntic mucosa of control rats (group I) or rats dosed with either ciprofibrate (group II), octreotide LAR (group III) or a combination of both (group IV) for 60 days. All values are mean \pm s.E.M. $* P<0 \cdot 05, * * * P<0 \cdot 001$ vs control or as indicated. 

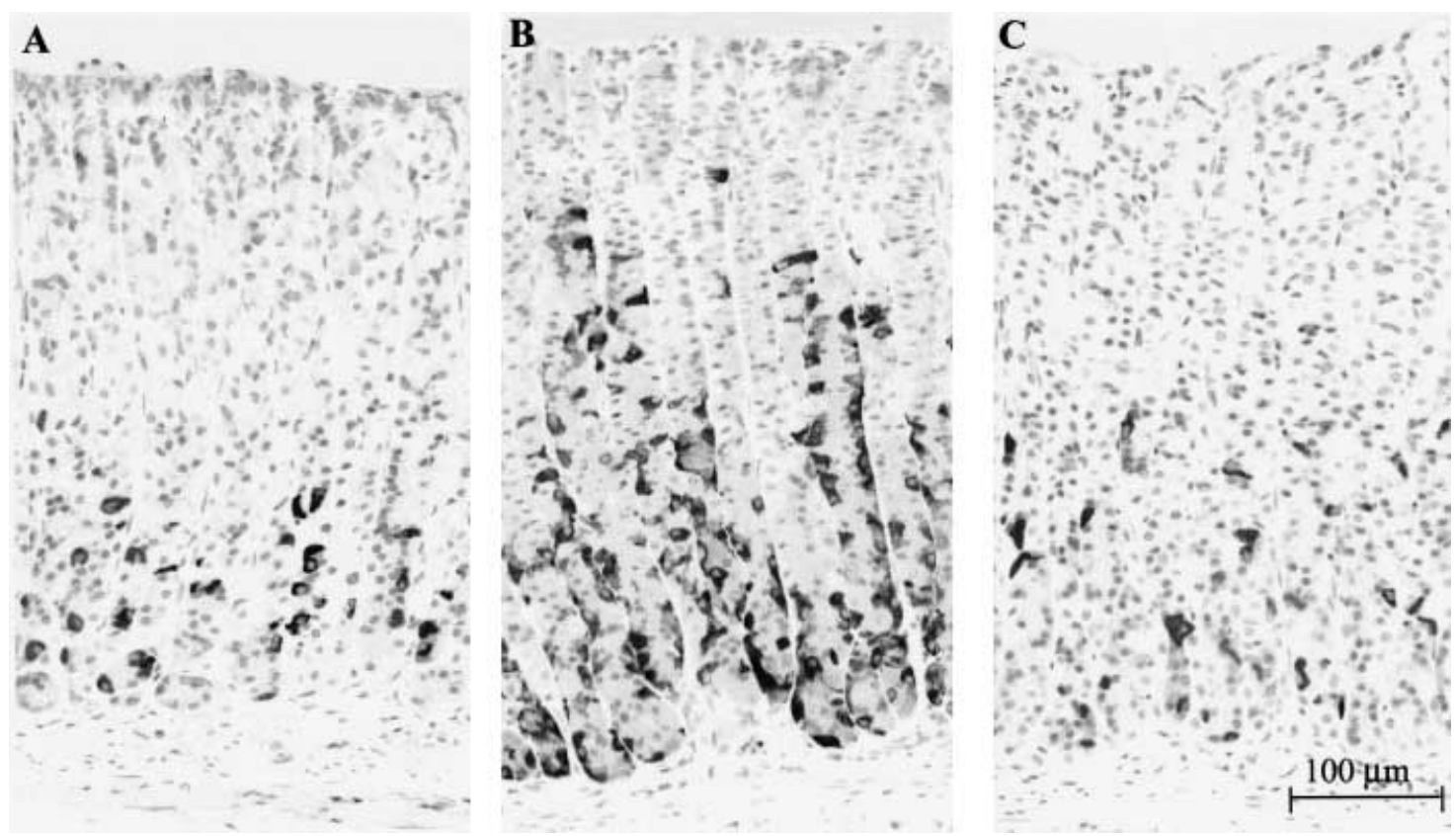

FIGURE 8. HDC-immunoreactive cells in corpus of control rats (group I) (A), rats dosed with ciprofibrate (group II) (B), or a combination of ciprofibrate and octreotide LAR (group IV) (C) for 60 days.

ciprofibrate did not reduce $G$ cell hyperfunction compared with ciprofibrate alone, and thus this study shows no functional or antiproliferative effect of octreotide on the $\mathrm{G}$ cell. This is different from other studies showing that octreotide reduces both hypergastrinemia caused by acid secretory inhibition (Modlin et al. 1992, Kimura 1993) and in different pathophysiological conditions (Bordi et al. 1993, D'Adda et al. 1996). The exact mechanism by which ciprofibrate induces hypergastrinemia is not known, but the present data, together with previous results (Hammer et al. 1998), show a mechanism fundamentally different from what is found during acid suppression. It is accepted that the molecular target for the fibrates is the $\alpha$-subtype of the nuclear peroxisome proliferator-activated receptor (PPAR) family (Issemann \& Green 1990). The precise cellular location of this receptor in the stomach is not known, but at least in the rat it is found throughout the digestive tract (Braissant et al. 1996). Whether fibrates bind directly to PPAR- $\alpha$ or activate it indirectly by altering the metabolism of an unknown endogenous ligand, is still unsettled (Kliewer et al. 1999). Peroxisome proliferators, including the fibrates, are lipid soluble and cross the cell membrane to activate the nuclear receptors that act directly as transcriptional factors regulating expression of genes (Issemann \& Green 1990). On the other hand, at least somatostatin and probably also antral luminal $\mathrm{H}^{+}$ions, regulate $\mathrm{G}$ cells via surface receptors. These different mechanisms might explain why ciprofibrate-induced hyperfunction of the $G$ cell is independent of both luminal $\mathrm{pH}$ and octreotide.

The hypergastrinemia in the group receiving ciprofibrate induced, as expected, a pronounced hypertrophy and hyperplasia of the ECL cells in oxyntic mucosa, confirmed by increases in the number and area of CgA-immunoreactive and ECL cells, HDC and CgA mRNA abundances and plasma histamine level. In the normal rat corpus, the ECL cell is the most abundant neuroendocrine cell (Sundler \& Hakanson 1991), and variation in $\mathrm{CgA}$ parameters represents changes in the ECL cell population. The specific trophic effect exerted by gastrin on the ECL cells in group II results in an even greater dominance of the total number of neuroendocrine cells, and explains the equal densities of ECL and CgA-immunoreactive cells in this group (Fig. 5). The results are comparable with findings in other studies evaluating the trophic effects of hypergastrinemia (Ryberg et al. 1989, Brenna \& Waldum 1992, Waldum et al. 1998). Comparison of the $\mathrm{H}^{+} / \mathrm{K}^{+}$ATPase-immunoreactive area in corpus sections from all groups did not reveal any differences. Thus, in this study there is no indication that gastrin or octreotide affects the density of parietal cells. Administration of 
octreotide in combination with ciprofibrate resulted in a pronounced decrease in all parameters representing the ECL cell population, reaching near control group levels. Since the hypergastrinemia in this group was sustained (144 pmol/l) and equal to the plasma gastrin level in group II (145 pmol/l), it seems obvious that octreotide has a direct effect on the ECL cells, reducing expression of HDC and $\mathrm{CgA}$ mRNA, histamine release and cellular proliferation. This is consistent with localization of the SSTR-2 on ECL cells (Borin et al. 1996), and similar suppression has been seen in other studies on both humans and rats (Cadiot et al. 1988, Modlin et al. 1992, Bordi et al. 1993, Tsutsui et al. 1995, Borin et al. 1996, D’Adda et al. 1996). However, most of these studies observed a significant reduction of plasma gastrin concentration (Modlin et al. 1992, Bordi et al. 1993, D'Adda et al. 1996) and therefore suggest that octreotide inhibits the ECL cells mainly by reversing the hypergastrinemia and not directly. Cadiot et al. (1988) observed a tendency to reduction in fundic argyrophil cell density after 70 days' administration of the somatostatin analog SMS (201-995) and omeprazole to rats, despite unchanged plasma gastrin levels. However, to our knowledge the present work is the first long-term study that, in addition to inhibition of ECL cell function, also shows a direct antiproliferative effect of octreotide on rat ECL cells that are continuously stimulated by gastrin. This study not only shows an inhibitory effect of octreotide on the gastrinstimulated ECL cell, but also a significant reduction of basal ECL cell function and growth, as seen in the group dosed with octreotide alone.

Contrary to previous studies (Hammer et al. 1998, Waldum et al. 1998), we found no obvious stimulating effect of ciprofibrate on the antral D cell. However, somatostatin mRNA abundance and area of D cells in group II tended to be increased, and the lack of reduction in $\mathrm{D}$ cell parameters accompanying the increase in $\mathrm{G}$ cell parameters, is alone in obvious contrast to their normal reciprocal relationship (Lundell et al. 1988, Wu et al. 1991). The lower dose of ciprofibrate in this study (50 mg/kg body weight) compared with earlier studies $(100 \mathrm{mg} / \mathrm{kg}$ body weight), may explain the difference in effect on antral D cells. Ciprofibrate dosing slightly increases gastric acidity as a consequence of the hypergastrinemia (Martinsen et al. 1996), which could explain the marginal increases in somatostatin mRNA. Still, the decrease in luminal $\mathrm{pH}$ after ciprofibrate dosing was minute and administration of ciprofibrate together with omeprazole, which completely blocks acid secretion, did not reduce somatostatin mRNA expression.
Instead it resulted in a level higher than after dosing with omeprazole alone (Hammer et al. 1998). In the present study, dosing of ciprofibrate together with octreotide, which also inhibits acid secretion, gave a significant decrease in somatostatin mRNA abundance compared with both controls and group II, given only ciprofibrate. An even more pronounced decrease in somatostatin mRNA was also seen in group III receiving octreotide alone. Evaluating these results, a direct action on the antral $\mathrm{G}$ and $\mathrm{D}$ cells still seems the most probable explanation for the effect of ciprofibrate. Whether ciprofibrate reaches these cells from the gastric lumen or via the blood has not yet been settled. In a preliminary study using vascularly perfused stomachs, there was no immediate effect on gastrin release when the peroxisome proliferator clofibrate was added to the arterial perfusate (K Iwaza \& H L Waldum, unpublished observations). Since oxyntic $\mathrm{D}$ cells are of the closed type and do not seem to be affected, it is possible that luminal ciprofibrate acts locally on endocrine cells of the open type (Waldum et al. 1998).

The hypergastrinemic effect of ciprofibrate begins relatively late (14 days), and a continuous administration of the drug is necessary to stimulate the $\mathrm{G}$ cell hyperfunction. To our knowledge, there are no cell lines derived from antral $G$ cells or other gastric endocrine cells that are functional and retain their characteristics, thus being available for long-term studies. Acute models like primary cultures of isolated G cells or ECL cells, that could have helped understand the cellular and molecular basis of ciprofibrate action, are unsuitable due to the long period of stimulation before effects can be observed. In the present study, the $G$ cell activity increased slightly in the group receiving only octreotide. Apparently, elevated gastric luminal $\mathrm{pH}$ due to octreotide suppression of the oxyntic mucosa stimulates $G$ cell function to overcome the direct inhibitory effect of octreotide. Few comparable studies have been done to measure the long-term effects of somatostatin analogs on intragastric $\mathrm{pH}$, but generally previous results indicate that luminal $\mathrm{pH}$ and content are dominant regulators of both antral G and D cell functions (Lundell et al. 1988, Sandvik \& Waldum 1988, Dimaline et al. 1991, Wu et al. 1991, Kimura 1993, Westbrook et al. 1998).

Antral CgA does not increase in parallel with $\mathrm{G}$ cell parameters, but instead seems to follow antral somatostatin mRNA and D cell density. This confirms other studies showing that $\mathrm{D}$ cells and enterochromaffin cells (EC) are the main sources of $\mathrm{CgA}$ in antrum and that $\mathrm{G}$ cells mostly contain $\mathrm{CgB}$ (Portela-Gomes et al. 1997). The reductions in oxyntic somatostatin mRNA in all groups with 
plasma gastrin concentrations above normal are explained by the negative effect of circulating plasma gastrin, binding to CCK-B receptors on oxyntic D cells (Chen et al. 1992).

In conclusion, the present study shows that octreotide does not reverse ciprofibrate-induced hypergastrinemia, indicating that ciprofibrate stimulates antral $\mathrm{G}$ cells by a mechanism which, in addition to being independent of luminal $\mathrm{pH}$, is unaffected by the normal suppressive action of somatostatin. This seems to be a novel mechanism, fundamentally different from other $G$ cellstimulating conditions in the stomach. On the other hand, the ECL cell hypertrophy and hyperplasia following ciprofibrate-induced hypergastrinemia are significantly reduced by octreotide, despite maintained stimulation by gastrin. Octreotide also has a substantial inhibitory effect on basal ECL cell function and growth. This is the first long-term study on rats that shows direct antiproliferative effects of octreotide on ECL cells independent of changes in plasma gastrin.

\section{ACKNOWLEDGEMENTS}

We thank Hege Rørvik, Bjørn Munkvold, Britt Schulze, Anne Kristensen and Gunnar Qvigstad for their technical assistance. This work was supported by The Research Council of Norway.

\section{REFERENCES}

Angelsen A, Mecsei R, Sandvik AK \& Waldum HL 1997 Neuroendocrine cells in the prostate of the rat, guinea pig, cat, and dog. Prostate 33 18-25.

Bordi C, Azzoni C, Pilato FP, Robutti F, D'Ambra G, Caruana P, Rindi G, Corleto VD, Annibale B \& Delle FG 1993 Morphometry of gastric endocrine cells in hypergastrinemic patients treated with the somatostatin analogue octreotide. Regulatory Peptides 47 307-318.

Borin JF, Tang LH, Kidd M, Miu K, Bortecen KH, Sandor A \& Modlin IM 1996 Somatostatin receptor regulation of gastric enterochromaffin-like cell transformation to gastric carcinoid. Surgery 120 1026-1032.

Braissant O, Foufelle F, Scotto C, Dauca M \& Wahli W 1996 Differential expression of peroxisome proliferator-activated receptors (PPARs): tissue distribution of PPAR-alpha, -beta, and -gamma in the adult rat. Endocrinology 137 354-366.

Brenna E \& Waldum HL 1992 Trophic effect of gastrin on the enterochromaffin like cells of the rat stomach: establishment of a dose response relationship. Gut 33 1303-1306.

Cadiot G, Lehy T \& Bonfils S 1988 Action of somatostatin analogue (SMS 201-995) on the growth-promoting effect resulting from sustained achlorhydria in rat gastric mucosa, with special reference to endocrine cell behaviour. European Fournal of Clinical Investigation 18 360-368.

Chan YL, Gutell R, Noller HF \& Wool IG 1984 The nucleotide sequence of a rat $18 \mathrm{~S}$ ribosomal ribonucleic acid gene and a proposal for the secondary structure of $18 \mathrm{~S}$ ribosomal nucleic acid. Fournal of Biological Chemistry 259 224-230.

Chen D, Uribe A, Hakanson R \& Sundler F 1992 Somatostatin cells in the oxyntic mucosa of hypo- or hypergastrinemic rats. Scandinavian Fournal of Gastroenterology 27 479-482.

D'Adda T, Annibale B, Delle FG \& Bordi C 1996 Oxyntic endocrine cells of hypergastrinaemic patients. Differential response to antrectomy or octreotide. Gut 38 668-674.

Dimaline R, Evans D, Varro A \& Dockray GJ 1991 Reversal by omeprazole of the depression of gastrin cell function by fasting in the rat. Fournal of Physiology $\mathbf{4 3 3}$ 483-493.

Eason CT, Pattison A, Howells DD \& Bonner FW 1988a The effect of ciprofibrate on gastric secretion in the rat. Fournal of Pharmacy and Pharmacology 40 512-513.

Eason CT, Pattison A, Howells DD, Spencer AJ \& Bonner FW $1988 b$ Assessment of gastric antisecretory effects of phenoxyisobutyrate derivatives in the rat and the mouse. Scandinavian Fournal of Gastroenterology 23 1063-1071.

Eason CT, Spencer AJ, Pattison A, Howells DD, Henry DC \& Bonner FW 1988c Species variation in gastric toxicity following chronic administration of ciprofibrate to rat, mouse, and marmoset. Toxicology and Applied Pharmacology $95328-338$.

Hammer TA, Sandvik AK \& Waldum HL 1998 Potentiating hypergastrinemic effect by the peroxisome proliferator ciprofibrate and omeprazole in the rat. Scandinavian fournal of Gastroenterology 33 595-599.

Holst JJ, Knuhtsen S, Orskov C, Skak-Nielsen T, Poulsen SS \& Nielsen OV 1987 GRP-producing nerves control antral somatostatin and gastrin secretion in pigs. American fournal of Physiology 253 G767-G774.

Issemann I \& Green S 1990 Activation of a member of the steroid hormone receptor superfamily by peroxisome proliferators (see comments). Nature 347 645-650.

Karnik PS, Monahan SJ \& Wolfe MM 1989 Inhibition of gastrin gene expression by somatostatin. Fournal of Clinical Investigation 83 367-372.

Kimura K 1993 Effect of a somatostatin analogue (SMS 201-995) on antral gastrin cell hyperplasia and hypergastrinemia induced by a histamine $\mathrm{H} 2$-receptor antagonist. Scandinavian Fournal of Gastroenterology 28 413-417.

Kleveland PM, Haugen SE \& Waldum HL 1985 The preparation of bioactive ${ }^{125} \mathrm{I}$-gastrin, using Iodo-gen as oxidizing agent, and the use of this tracer in receptor studies. Scandinavian Fournal of Gastroenterology 20 569-576.

Kliewer SA, Lehmann JM \& Willson TM 1999 Orphan nuclear receptors: shifting endocrinology into reverse. Science $284757-760$.

Lamberts SW, Krenning EP \& Reubi JC 1991 The role of somatostatin and its analogs in the diagnosis and treatment of tumors. Endocrine Reviews 12 450-482.

Lundell L, Bishop AE, Bloom SR, Carlsson K, Mattsson H, Polak JM \& Ryberg B 1988 Gastrin and somatostatin in the rat antrum. The effect of removal of acid-secreting mucosa. Regulatory Peptides 23 77-87.

Martinsen TC, Nesjan N, Ronning K, Sandvik AK \& Waldum HL 1996 The peroxisome-proliferator ciprofibrate induces hypergastrinemia without raising gastric $\mathrm{pH}$. Carcinogenesis 17 2153-2155.

Modlin IM, Kumar R, Nangia A, Soroka CJ, Pasikhov D \& Goldenring JR 1992 Gastrin-dependent inhibitory effects of octreotide on the genesis of gastric ECLomas. Surgery 112 1048-1056.

O’Brien ML, Rangwala SM, Henry KW, Weinberger C, Crick DC, Waechter CJ, Feller DR \& Noonan DJ 1996 
Convergence of three steroid receptor pathways in the mediation of nongenotoxic hepatocarcinogenesis. Carcinogenesis 17 185-190.

Okazaki K, Miyata A, Sano S \& Yamamoto Y 1993 Effect of short-term administration of dexamethasone on canine antral gastrin gene expression. Digestion 54 130-134.

Portela-Gomes GM, Stridsberg M, Johansson H \& Grimelius L 1997 Complex co-localization of chromogranins and neurohormones in the human gastrointestinal tract. Fournal of Histochemistry and Cytochemistry 45 815-822.

Ryberg B, Bishop AE, Bloom SR, Carlsson E, Hakanson R, Larsson H, Mattsson H, Polak JM \& Sundler F 1989 Omeprazole and ranitidine, antisecretagogues with different modes of action, are equally effective in causing hyperplasia of enterochromaffin-like cells in rat stomach. Regulatory Peptides 5 235-246.

Saffouri B, Weir GC, Bitar KN \& Makhlouf GM 1980 Gastrin and somatostatin secretion by perfused rat stomach: functional linkage of antral peptides. American Fournal of Physiology 238 G495-G501.

Sandvik AK \& Waldum HL 1988 The effect of somatostatin on baseline and stimulated acid secretion and vascular histamine release from the totally isolated vascularly perfused rat stomach. Regulatory Peptides 20 233-239.

Sandvik AK, Holst JJ \& Waldum HL 1989 The effect of gastrin-releasing peptide on acid secretion and the release of gastrin, somatostatin, and histamine in the totally isolated, vascularly perfused rat stomach. Scandinavian Fournal of Gastroenterology 24 9-15.

Sandvik AK, Brenna E, Sundan A, Holst JJ \& Waldum HI 1997 Bombesin inhibits histamine release from the rat oxyntic mucosa by a somatostatin-dependent mechanism. Scandinavian Fournal of Gastroenterology 32 427-432.

Spencer AJ, Barbolt TA, Henry DC, Eason CT, Sauerschell RJ \& Bonner FW 1989 Gastric morphological changes including carcinoid tumors in animals treated with a potent hypolipidemic agent, ciprofibrate. Toxicology and Pathology 17 7-15.
Sundler F \& Hakanson R 1991 Gastric endocrine cell typing at the light microscope level. In The Stomach as an Endocrine Organ, pp 9-26. Eds R Hakanson \& F Sundler. Amsterdam: Elsevier.

Tsutsui S, Shinomura Y, Kanayama S, Yabu M, Miyazaki Y, Kawabata S, Kondo S, Murayama Y, Imamura I \& Matsuzawa Y 1995 Inhibition of gastrin-stimulated enterochromaffin-like cell proliferation and mucosal histamine production in the rat stomach by the somatostatin analogue octreotide. Regulatory Peptides 57 175-182.

Waldum HL, Brenna E, Sandvik AK, Kleveland PM, Petersen H \& Sognen B 1989 Histamine and gastrin in plasma of patients with upper gastrointestinal diseases. Digestion 42 121-127.

Waldum HL, Kvetnoi IM, Sylte R, Schulze B, Martinsen TC \& Sandvik AK 1998 The effect of the peroxisome proliferator ciprofibrate on the gastric mucosa and particularly the gastrin cell. Fournal of Molecular Endocrinology 20 111-117.

Westbrook SL, McDowell GH, Hardy KJ \& Shulkes A 1998 Active immunization against somatostatin alters regulation of gastrin in response to gastric acid secretagogues. American Fournal of Physiology 274 G751-G756.

Wu V, Sumii K, Tari A, Sumii M \& Walsh JH 1991 Regulation of rat antral gastrin and somatostatin gene expression during starvation and after refeeding. Gastroenterology 101 1552-1558.

Xynos E, Vassilakis JS, Neonakis E, Fountos A \& Kittas C 1987 Alterations in serum gastrin levels and antral G-and D-cell population following corticosteroid administration. RIA and immunocytochemical long-term study in guinea pigs. Digestion 36 7-12.

Zaki M, Harrington L, McCuen R, Coy DH, Arimura A \& Schubert ML 1996 Somatostatin receptor subtype 2 mediates inhibition of gastrin and histamine secretion from human, dog, and rat antrum. Gastroenterology 111 919-924.

REVISED MANUSCRIPT RECEIVED 23 March 2000 